\title{
Pengujian Ekstrak Sederhana Bagian Tumbuhan Cassia alata Linnaeus terhadap Colletotrichum Gloeosporioides secara Invitro
}

\section{Bioassay of Cassia alata Linnaeus crude extracts on Colletotrichum gloeosporioides in Vitro}

\author{
Arneti $^{1)^{*}}$, Eri Sulyanti ${ }^{1)}$, Murniati ${ }^{2)}$ \\ 1) Program Studi Proteksi Tanaman Fakultas Pertanian Universitas Andalas Padang \\ 2) Program Studi Agroteknologi Fakultas Pertanian Universitas Andalas Padang \\ E-mail: arneti_astri@yahoo.com
}

\begin{abstract}
Plant extracts have been known to cause inhibit the growth of Colletotrichum gloeosporioides. This study was aimed to determine the most potential part of Cassia alata crude extract to control antrachnose on chili. The study was conducted in Phytopathology Laboratory, Plant Pests and Diseases Department, Agriculture Faculty, Andalas University, from April to June 2015. The research used Completely Randomized Design (CRD) with seven treatments and five replications. The treatments were several extracts from different parts of C. Alata: 1) control 2) flower, 3) old leaf, 4) young leaf, 5) stem, 6) root, and 7) seed with concentration of $5 \%$ respectively. Variables observed were colony growth, colony width, conidia number, colony wet and dry weight, and conidia germination. The result showed that all of $C$. alata extracts could inhibit the growth of $C$. gloeosporioides in vitro. The best extract was from the old leaf with the percentage of colony width, conidia number, colony wet and dry weight, and conidia germination of $64,30 \%, 82,41 \%, 37,77$, $29,8 \%$, and $79,96 \%$ respectively.
\end{abstract}

Keywords: crude plant extract, Cassia alata, C. gloeosporioides, anthracnose disease

\section{PENDAHULUAN}

Cabai (Capsicum annum) merupakan salah satu komodititas hortikultura yang penting dan banyak dibudidayakan petani karena kegunaannya sebagian besar untuk konsumsi. Sumatera Barat mem-punyai potensi sebagai produsen cabai karena iklim dan lingkungan yang memenuhi syarat bagi pertumbuhan dan perkembangannya. Produktivitas cabai di Sumatera Barat lima tahun terakhir tidak mengalami peningkatan yang signifikan. Badan Pusat Statistik (2014) melaporkan bahwa tahun 2009 produktivitas cabai mencapai 6,05 ton/ha, tahun 2010 menjadi 6,56 ton/ha, tahun 2011 meningkat menjadi 7,30 ton/ha, pada tahun 2012 adalah 7,94 ton/ha, sedangkan pada tahun 2013 yaitu 7,60 ton/ha. Angka tersebut masih rendah apabila dibandingkan dengan potensi produktivitasnya yakni dapat mencapai 12 ton per hektar (Syukur et al., 2013).

Rendahnya produktivitas cabai disebabkan oleh be-berapa faktor diantaranya pembibitan, pengolahan tanah, penanaman dan pe-manenan yang kurang baik, serta adanya serangan organisme pengganggu tanaman seperti hama dan patogen. Salah satu penyakit tanaman 
cabai yang disebabkan oleh patogen adalah antraknosa (Ali et al., 2009).

Antraknosa merupakan penyakit utama tanaman cabai yang disebabkan oleh tiga species jamur Colletotrichum, yaitu C. acutatum, C. capsici, dan $C$. gloeosporioides (AVRDC, 2003). Inang utama dari $C$. Gloeosporioides adalah cabai. Jamur ini juga dapat menyerang tanaman solanaceae lainnya (Efri, 2010).

Gejala serangan jamur $C$. gloeosporioides pada daun dan buah terdapatnya bercak kecil yang kemudian melebar, pada batang dan tangkai daun menyebabkan nekrosis, dan pada bagian titik tumbuh menyebabkan tanaman mati pucuk dan tidak dapat berkembang (Gautam, 2014).

Kehilangan hasil tanaman cabai akibat serangan antraknosa pada musim hujan lebih tinggi dibandingkan musim kemarau. Kehilangan hasil pada musim hujan adalah sebesar 50-100\% (Hariati 2007), sedangkan pada musim kemarau adalah sebesar 2-35\% (Widodo 2007). Secara umum, kerusakan yang disebabkan oleh C. gloeosporioides dapat menyebabkan kehilangan hasil hingga 90\% (Park, 2005). Serangan C. gloeosporioides pada buah cabai rentan, dengan kondisi lingkungan yang sesuai, dapat menimbulkan kerusakan yang serius (Ratulangi et al., 2012).

Pengendalian penyakit antraknosa yang banyak dilakukan petani adalah dengan menggunakan fungisida sintetik, namun penggunaan secara intensif dan terus menerus menimbulkan dampak negatif karena fungisida sintetik meninggalkan residu dalam konsentrasi yang tinggi pada lingkungan, serta membahayakan petani dan konsumen (Gusti, 2003; Efri, 2010). Pemanfaatan fungisida nabati merupakan pengendalian alternatif yang berpotensi untuk mengendalikan penyakit tanaman serta aman bagi ling- kungan dan bahan-bahannya mudah diperoleh (Kardinan, 2011).

Cassia alata Linnaeus (Ketepeng cina) merupakan salah satu tumbuhan yang dapat digunakan sebagai fungisida nabati karena mengandung beberapa senyawa kimia yang berfungsi sebagai anti jamur. Senyawa kimia tersebut dihasilkan dari proses metabolisme yang terjadi pada daun, batang, bunga akar dan bijinya. Senyawa kimia tersebut antara lain berupa flavonoid, tanin, alkaloid, saponin, antrakuinon, asam krisofanat, crysophanic, naphtoquonine, resin dan juga minyak atsiri yang diproduksi dalam jumlah sedikit yang sebarannya pada bagian tumbuhan tidaklah sama (Doughari and Okafor, 2007; Nwachukwu dan Osuji, 2008; Dalimartha, 2009).

Penelitian Wongkaew dan Sisri (2014) menyatakan bahwa ekstrak kasar daun tumbuhan $C$. alata memiliki kemam-puan menghambat pertumbuhan miselia beberapa jamur penyebab penyakit tanaman diantaranya Alternaria alternata, Fusarium oxysporum f.sp. lycopersici, Sclerotium rolfsii, Phytophthora infestans dan Pythium sp. Suleiman et al. (2008) menyatakan bahwa ekstrak daun $C$. alata juga mampu menghambat pertumbuhan miselia jamur Fusarium sp. pada konsentrasi 3,5\% dengan daya hambat $100 \%$. Penelitian ini bertujuan untuk mengetahui bagian tanaman C. alata yang paling berpengaruh dalam mengendalikan penyakit antraknosa pada cabai.

\section{METODOLOGI}

Penelitian telah dilaksanakan di Laboratorium Fitopatologi Jurusan Hama dan Penyakit Tumbuhan Fakultas Pertanian Universitas Andalas dimulai dari bulan April sampai Juni 2015.

\section{Rancangan}

Penelitian menggunakan Rancangan Acak Lengkap (RAL) dengan 7 
perlakuan dan 5 ulangan. Perlakuannya adalah ekstrak bagian tumbuhan C.alata masing-masing dengan konsentrasi $5 \%$ sebagai berikut : kontrol, bunga, daun tua, daun muda, batang, akar, dan biji.

\section{Isolasi jamur}

Jamur C. gloeosporioides diisolasi dari cabai yang bergejala antraknosa dengan menggunakan metode tanam langsung pada medium PDA. Bagian tanaman yang terserang dipotong ukuran $1 \times 1 \mathrm{~cm}$ dengan menyertakan jaringan yang sehat. Potongan sampel disterilisasi per-mukaan dengan cara memasukkan ke dalam akuades (selama 60 detik) alkohol 70\% (30 detik) - akuades (60 detik) dan kemudian dikering-anginkan. Selanjutnya potongan tersebut diletakkan di dalam cawan petri yang telah berisi medium PDA, sebanyak 5 potongan/petri dan diinkubasi selama 3 hari pada suhu ruangan. Setelah 3 hari isolasi, jamur yang tumbuh dipin-dahkan ke medium PDA sampai didapatkan biakan murni dari jamur tersebut (Ilma, 2009), dilanjutkan dengan identifikasi yang berpedoman pada Barnet HL dan Hunter (1972) melalui pengamatan bentuk dan warna koloni, bentuk dan warna konidia, ada atau tidaknya setae, serta ada atau tidaknya sekat pada hifa.

\section{Pembuatan ekstrak $C$. alata}

Tumbuhan C. alata diambil di Nagari Campago, Kecamatan V Koto Kampung Dalam, Kabupaten Padang Pariaman, Sumatera Barat. Kriteria bagian tumbuhan yang dijadikan ekstrak adalah bunga yang sudah terbuka dan berwarna kuning, daun ketiga dan daun kelima dari pucuk, batang dan akar yang masih lunak dan belum mengeras menjadi kayu, serta biji yang sudah tua dan menghitam. Ekstrak dibuat dengan cara mengambil 5 gram semua bagian tumbuhan $C$. alata dan ditambahkan akuades steril $100 \mathrm{ml}$ selanjutnya diblender sampai halus.
Kemudian dimasukkan ke dalam erlenmeyer steril dan ditutup dengan aluminium foil. Selanjutnya ekstrak dipanaskan hingga mendidih. Setelah 15 menit mendidih, kemudian disaring dengan menggunakan kertas saring steril.

\section{Pengamatan}

\section{Pertumbuhan koloni jamur}

Pengujian dilakukan dengan cara mencampurkan $1 \mathrm{ml}$ dari masing-masing perlakuan dengan $9 \mathrm{ml}$ PDA di dalam tabung reaksi dan dihomogenkan dengan menggunakan vorteks, lalu dituangkan ke dalam cawan petri. Setelah membeku diinokulasikan ditengah-tengahnya jamur C. gloeosporioides dengan ukuran $7 \mathrm{~mm}$ (ukuran corck borer) dan semua perlakuan disimpan dalam suhu ruangan sampai cawan petri pada kontrol dipenuhi jamur (umur 14 hari). Pengamatan dengan melihat penyebaran koloni, warna dan ketebalan koloni.

\section{Luas koloni jamur $\left(\mathrm{cm}^{2}\right)$}

Pengamatan dilakukan setiap hari dimulai dari hari ke-2 setelah inokulasi sampai cawan petri pada kontrol telah dipenuhi jamur (hari ke -14). Cara mengukur luas koloni pada tiap-tiap cawan petri dengan menggunakan kertas milimeter plotting dengan menggambar luas koloni tersebut pada plastik kaca.

\section{Jumlah konidia jamur}

Penghitungan jumlah konidia dilakukan dengan menambahkan $10 \mathrm{ml}$ akuades steril ke dalam cawan petri yang berisi biakan jamur (hari ke-14). Kemudian konidia dilepas dengan menggunakan kuas dan didapatkan suspensi jamur. Selan-jutnya dilakukan pengenceran sampai $10^{-1}$, dari suspensi tersebut diambil 1 tetes dengan pipet tetes dan dihitung dengan haemocytometer.

Penghitungan jumlah konidia dilakukan dengan cara memilih 5 kotak B secara diagonal (1 kotak B terdiri dari 16 
kotak C) dengan menggunakan haemocytometer improve neubuer. Jumlah konidia jamur / $\mathrm{ml}$ suspensi dapat dihitung dengan mencari jumlah rata-rata konidia pada kotak $\mathrm{C}$ yang diamati kemudian dikali dengan $4 \times 10^{6} \mathrm{sel} / \mathrm{ml}$.

\section{Berat basah koloni jamur (g)}

Berat basah koloni jamur ditimbang pada hari ke 14 setelah cawan petri kontrol dipenuhi jamur, dilakukan dengan

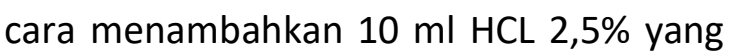
telah dipanaskan dengan suhu $100^{\circ} \mathrm{C}$ untuk melarutkan agar, kemudian disaring deng-an kertas saring Whatman No. 40 dan ditimbang dengan timbangan analitik.

\section{Berat kering koloni jamur (g)}

Berat kering koloni jamur $C$. gloeosporioides dihitung dengan cara: miselium yang telah disaring dengan kertas saring Whatman No. 40 dikeringkan dengan oven pada suhu $60^{\circ} \mathrm{C}$ selama 2 hari (sampai berat kering konstan), selanjutnya berat kering ditimbang dengan timbangan analitik.

\section{Daya perkecambahan konidia jamur}

Untuk mengetahui kemampuan fungisida ekstrak tumbuhan $C$. alata dalam menekan perkecambahan konidia secara in vitro, dilakukan dengan metode Slide germination (perkecambahan konidia). Gelas objek dicelupkan ke dalam masing-masing perlakuan selama satu menit, lalu dikering-anginkan. Selanjutnya diteteskan suspensi konidia jamur 0,05 ml dengan kerapatan 50000 spora/ml suspensi ke dalam gelas objek tersebut. Setiap tetes diupayakan agar menyebar pada diameter $10 \mathrm{~mm}$ dengan menggoyang-goyangkan. Kemudian gelas objek disimpan dalam cawan petri yang telah dialasi kertas saring dan dibasahi air steril serta disimpan diruang lembab. Pengamatan daya kecam-bah dilakukan 1 $x \quad 24$ jam setelah suspensi konidia diteteskan (Prijono, 2004).

\section{Analisis data}

Data hasil pengamatan dianalisis menggunakan Uji F secara acak lengkap (RAL). Jika menunjukkan perbedaan nyata, diuji lanjut menggunakan LSD pada taraf nyata $5 \%$.

Persentase penekanan masingmasing ekstrak ketepeng cina terhadap luas koloni, jumlah konidia, berat basah, berat kering, dan perkecambahan konidia dari jamur C. gloeosporioides dapat dihitung dengan menggunakan rumus (Prijono 2004) :

Keterangan:

$$
P=\frac{K-P}{K} \times 100
$$

$\mathrm{P}=$ Persentase penekanan (\%)

$\mathrm{K}=$ data pengamatan pada kontrol

$P=$ data pengamatan pada perlakuan

\section{HASIL}

\section{Pertumbuhan koloni jamur}

Pertumbuhan koloni jamur $C$. gloeosporioides dengan perlakuan ekstrak sederhana bagian tumbuhan $C$. alata dapat di lihat pada Tabel 1.

Pada Tabel 1 terlihat bahwa pemberian ekstrak tumbuhan $C$. alata dapat mempengaruhi ketebalan, luas dan warna koloni jamur C. gloeosporioides. Perlakuan dengan ekstrak tumbuhan $C$. alata dan kontrol menunjukkan penyebaran koloni miselia melingkar secara konsentris.

Warna koloni tampak atas pada perlakuan kontrol berwarna putih keabuabuan dan tampak bawah juga berwarna putih keabu-abuan tetapi dengan bagian tengah agak berwarna oranye. Sementara itu, warna koloni tampak atas pada perlakuan ekstrak akar, biji, bunga, batang dan daun tua $C$. alata berwarna abu-abu kehitaman, sedangkan perlakuan ekstrak daun muda sama dengan kontrol.

Warna koloni tampak bawah pada perlakuan ekstrak akar, biji, dan daun tua tumbuhan C. alata berwarna abu-abu kehitaman dan pada perlakuan ekstrak bunga dan batang tumbuhan $C$. alata 
juga berwarna abu-abu kehitaman namun dengan bagian tengah agak berwarna oranye serta pada perlakuan ekstrak daun muda tumbuhan $C$. alata warna koloni tampak bawahnya berwarna putih keabuabuan dengan bagian tengah berwarna hitam.

\section{Luas koloni jamur}

Pemberian ekstrak tumbuhan $C$. alata dapat menekan pertumbuhan koloni jamur $C$. gloeosporioides dengan persentase penekanan berkisar antara 11,97 - 64,3\%. Penekanan tertinggi ditemukan pada perlakuan dengan ekstrak daun tua, meskipun tidak berbeda dengan ekstrak batang (Tabel 2).

Tabel 1. Pertumbuhan koloni jamur C. gloeosporioides dengan perlakuan ekstrak sederhana bagian tumbuhan C. alata (umur 14 hari)

\begin{tabular}{|c|c|c|c|c|}
\hline \multirow{2}{*}{ Perlakuan } & \multirow{2}{*}{ Penyebaran Koloni } & \multicolumn{2}{|c|}{ Warna Koloni } & \multirow{2}{*}{ Ketebalan Kolon } \\
\hline & & Tampak Atas & Tampak Bawah & \\
\hline Kontrol & $\begin{array}{l}\text { Melingkar secara } \\
\text { konsentris }\end{array}$ & $\begin{array}{l}\text { Putih keabu- } \\
\text { abuan }\end{array}$ & $\begin{array}{l}\text { Putih keabu-abuan, bagian } \\
\text { tengah agak oranye }\end{array}$ & Tebal $(++)$ \\
\hline Akar & $\begin{array}{l}\text { Melingkar secara } \\
\text { konsentris }\end{array}$ & $\begin{array}{l}\text { Abu-abu } \\
\text { kehitaman }\end{array}$ & Abu-abu kehitaman & Tebal $(++)$ \\
\hline Biji & $\begin{array}{l}\text { Melingkar secara } \\
\text { konsentris }\end{array}$ & $\begin{array}{l}\text { Abu-abu } \\
\text { kehitaman }\end{array}$ & Abu-abu kehitaman & Agak tebal (+) \\
\hline Bunga & $\begin{array}{l}\text { Melingkar secara } \\
\text { konsentris }\end{array}$ & $\begin{array}{l}\text { Abu-abu } \\
\text { kehitaman }\end{array}$ & $\begin{array}{l}\text { Abu-abu kehitaman, } \\
\text { bagian tengah agak oranye }\end{array}$ & Tipis (-) \\
\hline Daun muda & $\begin{array}{l}\text { Melingkar secara } \\
\text { konsentris }\end{array}$ & $\begin{array}{l}\text { Putih keabu- } \\
\text { abuan }\end{array}$ & $\begin{array}{l}\text { Putih keabu-abuan, bagian } \\
\text { tengah hitam }\end{array}$ & Agak tebal (+) \\
\hline Batang & $\begin{array}{l}\text { Melingkar secara } \\
\text { konsentris }\end{array}$ & $\begin{array}{l}\text { Abu-abu } \\
\text { kehitaman }\end{array}$ & $\begin{array}{l}\text { Abu-abu kehitaman, } \\
\text { dengan bagian tengah agak } \\
\text { oranye }\end{array}$ & Agak tebal (+) \\
\hline Daun tua & $\begin{array}{l}\text { Melingkar secara } \\
\text { konsentris }\end{array}$ & $\begin{array}{l}\text { Abu-abu } \\
\text { kehitaman }\end{array}$ & Abu-abu kehitaman & Agak tebal (+) \\
\hline
\end{tabular}

Tabel 2. Luas koloni dan persentase penekanan jamur C. gloeosporioides dengan perlakuan ekstrak sederhana bagian tumbuhan C. alata (umur 14 hari)

\begin{tabular}{llc}
\hline Perlakuan & Luas koloni $\left(\mathbf{c m}^{\mathbf{2}}\right)$ & Persentase Penekanan (\%) \\
\hline Kontrol & $61,81 \mathrm{a}$ & 0,00 \\
Akar & $54,41 \mathrm{ab}$ & 11,96 \\
Biji & $51,17 \mathrm{abc}$ & 17,21 \\
Bunga & $42,85 \mathrm{bc}$ & 30,68 \\
Daun muda & $38,95 \mathrm{~cd}$ & 38,40 \\
Batang & 26,96 de & 56,37 \\
Daun tua & $22,07 \quad$ e & 64,30 \\
\hline
\end{tabular}

Angka-angka pada lajur yang sama dan diikuti huruf yang sama adalah berbeda tidak nyata menurut DNMRT pada taraf $5 \%$.

Perkembangan luas koloni pada perlakuan ekstrak tumbuhan C. Alata juga relatif lebih lambat apabila dibandingkan dengan perkembangan luas koloni pada kontrol (Gambar 1). Pertumbuhan luas koloni jamur C. gloeosporioides pada semua perlakuan hampir sama dari hari pertama sampai dengan hari ke-3. Kemudian pada hari ke-4 terjadi pening- katan pertumbuhan hingga hari ke-14. Peningkatan terendah diperlihatkan oleh perlakuan ekstrak daun tua.

Jumlah konidia jamur

Jumlah konidia jamur $C$. gloeosporioides yang terbentuk dipengaruhi oleh luas koloni jamur. Semakin besar luas koloni jamur, maka jumlah 
konidia yang dihasilkan oleh jamur $C$. gloeosporioides juga semakin banyak, begitu juga sebaliknya. Perlakuan ekstrak daun tua tumbuhan $C$. alata mampu menekan pertumbuhan jumlah konidia dengan persentase penekanan yang paling tinggi yaitu lebih dari $82 \%$ (Tabel 3).

\section{Berat basah dan berat kering koloni jamur}

Berat basah dan kering koloni jamur C. gloeosporioides dapat dilihat pada Tabel 4. Perlakuan ekstrak daun tua memper-lihatkan berat basah dan kering terendah dibandingkan dengan perlakuan yang lain dengan persentase penekanan sebesar $37,77 \%$ untuk berat kering dan sebesar $29,8 \%$ untuk berat basah.

\section{Daya perkecambahan konidia jamur}

Ekstrak tumbuhan C. alata dapat menekan perkecambahan konidia jamur C. Gloeosporioides berkisar antara 23,7979,97\%. Hal tersebut dapat dilihat pada Tabel 5. Semua perlakuan ekstrak tumbuhan memperlihatkan penekanan daya kecambah yang nyata dibandingkan kontrol kecuali bagian akar. Persentase penekanan tertinggi didapatkan pada bagian daun tua sebesar $79,96 \%$.

\section{PEMBAHASAN}

Berdasarkan pengamatan terhadap ketebalan koloni terlihat bahwa ekstrak bunga tumbuhan $C$. alata efektif dalam menekan pertumbuhan miselia, sehingga miselia tampak tipis (-) apabila dibanding-kan dengan perlakuan kontrol. Tipisnya miselia pada perlakuan ekstrak bunga tumbuhan $C$. alata diduga sebagai akibat reaksi dari jamur terhadap kandungan senyawa anti jamur yang terkandung dalam ekstrak bunga tumbuhan C. alata. Menurut Lyr (1977) dalam Khairul (1991) bahwa apabila senyawa kimia kontak dengan sel jamur, akan mengganggu aktivitas sel jamur, seperti gangguan terhadap respirasi dan metabolisme.

Lambatnya laju perkembangan luas koloni jamur $C$. gloeosporioides diduga dipengaruhi oleh senyawa flavonoid yang terkandung pada tumbuhan C. alata. Senyawa flavonoid memiliki kemampuan dalam mengikat protein di dalam sel jamur sehingga menyebabkan pembentukan dinding sel jamur terhambat, dan pertum-buhan hifa juga terhambat karena komposisi dinding sel yang diperlukan tidak terpenuhi (Harborne, 1987 dalam Wati et al., 2012).

Menurut Aulifa et al. (2014) penggunaan ekstrak metanol daun $C$. alata mampu menghambat pertumbuhan mise-lium jamur Phytophtora palmivora penye-bab penyakit busuk buah kakao pada konsentrasi $1 \%$ dengan daya hambat 67,57\%. Selain itu Owoyale et al. (2005) menambahkan ekstrak daun tumbuhan $C$. alata juga mengandung alkohol. Senyawa alkohol mampu menghambat pertumbuhan jamur Rhizopus sp. dan Aspergillus niger dengan konsentrasi hambat minimum (MIC) sebesar $70 \mu \mathrm{g} / \mathrm{ml}$.

Pengamatan berat basah dan

berat kering koloni jamur $C$. gloeosporioides terlihat berbanding lurus dengan luas koloni jamur $C$. gloeosporioides. Luas koloni terbesar juga menunjukkan berat basah dan berat kering tertinggi, dan luas koloni terkecil juga menunjukkan berat basah dan berat kering terendah. Semakin kecil berat basah dan berat kering koloni jamur $C$. gloeosporioides artinya pertumbuhan koloni jamur juga semakin dipengaruhi oleh senyawa anti jamur yang terkandung dalam ekstrak tumbuhan $C$. alata. Salah satu senyawa anti jamurnya adalah terpenoid. Senyawa tersebut dapat menghambat pertumbuhan jamur, baik 


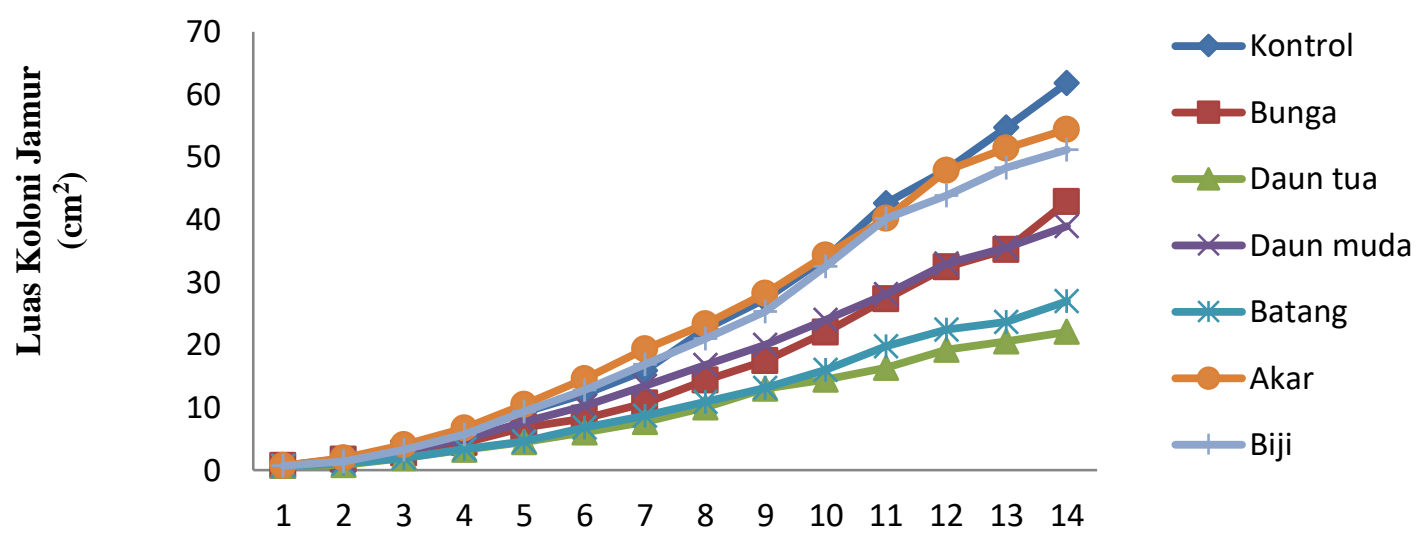

Hari Pengamatan

Gambar 1. Laju perkembangan luas koloni jamur C. gloeosporioides dengan perlakuan ekstrak sederhana bagian tumbuhan C. alata pada medium PDA dimulai pada hari pertama sampai dengan hari ke-14

Tabel 3. Jumlah konidia dan persentase penekanan jamur C. gloeosporioides/ml suspensi dengan perlakuan ekstrak sederhana bagian tumbuhan $C$. alata (umur 14 hari)

\begin{tabular}{lccc}
\hline Perlakuan & Jumlah konidia/ml suspensi & Persentase penekan \\
\hline Kontrol & $90 \times 10^{3}$ & a & 0,00 \\
Akar & $68 \times 10^{3}$ & ab & 21,97 \\
Biji & $30 \times 10^{3}$ & bc & 64,84 \\
Bunga & $24 \times 10^{3}$ & bc & 70,00 \\
Daun muda & $22 \times 10^{3}$ & bc & 70,32 \\
Batang & $22 \times 10^{3}$ & bc & 73,62 \\
Daun tua & $14 \times 10^{3}$ & c & 82,41
\end{tabular}

Angka-angka pada lajur yang sama dan diikuti huruf yang sama adalah berbeda tidak nyata menurut DNMRT pada taraf $5 \%$.

Tabel 4. Berat basah dan berat kering koloni jamur C. gloeosporioides dengan perlakuan ekstrak sederhana bagian tumbuhan $C$. alata (umur 14 hari)

\begin{tabular}{lcccc}
\hline Perlakuan & $\begin{array}{c}\text { Berat basah } \\
\text { (gram) }\end{array}$ & $\begin{array}{c}\text { Persentase } \\
\text { Penekanan (\%) }\end{array}$ & $\begin{array}{c}\text { Berat kering } \\
\text { (gram) }\end{array}$ & $\begin{array}{c}\text { Persentase } \\
\text { Penekanan (\%) }\end{array}$ \\
\hline Kontrol & $3,89 \mathrm{a}$ & 0,00 & $0,79 \mathrm{a}$ & 0,0 \\
Akar & $3,88 \mathrm{ab}$ & 0,25 & $0,78 \mathrm{a}$ & 0,4 \\
Biji & $3,56 \mathrm{ab}$ & 8,38 & $0,62 \mathrm{ab}$ & 16,0 \\
Bunga & $3,38 \mathrm{ab}$ & 13,12 & $0,60 \mathrm{ab}$ & 18,4 \\
Daun muda & $3,37 \mathrm{ab}$ & 13,32 & $0,56 \mathrm{~b}$ & 22,0 \\
Batang & $2,90 \mathrm{bc}$ & 25,47 & $0,52 \mathrm{~b}$ & 26,4 \\
Daun tua & $2,42 \mathrm{c}$ & 37,77 & $0,49 \mathrm{~b}$ & 29,8 \\
\hline
\end{tabular}

Angka-angka pada lajur yang sama dan diikuti huruf yang sama adalah berbeda tidak nyata menurut DNMRT pada taraf $5 \%$. 
Tabel 5. Daya kecambah konidia jamur $C$. gloeosporioides akibat perlakuan ekstrak sederhana bagian tumbuhan C. alata (umur 14 hari).

\begin{tabular}{llrr}
\hline Perlakuan & \multicolumn{2}{l}{$\begin{array}{l}\text { Daya } \\
\text { kecambah }\end{array}$} & $\begin{array}{l}\text { Persentase } \\
\text { Penekanan (\%) }\end{array}$ \\
\hline Kontrol & 91,60 & a & 0,00 \\
Akar & 69,80 & ab & 23,79 \\
Biji & 57,20 & b & 37,55 \\
Bunga & 29,00 & c & 68,34 \\
Daun muda & 28,60 & c & 68,77 \\
Batang & 27,60 & c & 69,86 \\
Daun tua & 26,60 & c & 79,96 \\
\hline
\end{tabular}

Angka-angka pada lajur yang sama dan diikuti huruf yang sama adalah berbeda tidak nyata menurut DNMRT pada taraf $5 \%$.

melalui membran sitoplasma maupun mengganggu pertumbuhan dan perkembangan spora jamur (Lutfiyanti et al, 2012). Natta et al. (2008), menyatakan bahwa mekanisme penghambatan oleh senyawa terpenoid masih belum diketahui dengan jelas. Namun dengan adanya sifat hidrofobik atau lipofilik senyawa terpenoid kemungkinan menyebabkan kerusakan sitoplasmik membran, koagulasi sel, dan terjadinya gangguan proton pada sel jamur.

Hasil uji daya perkecambahan konidia jamur $C$. gloeosporioides, menunjukkan bahwa ekstrak tumbuhan $C$. alata dapat menekan perkecambahan konidia jamur C. gloeosporioides. Semangun (2000) menyatakan bahwa beberapa senyawa kimia seperti asam, minyak ester, dapat menghambat proses pembentukan dinding sel yang diperlukan untuk memanjangnya ujung hifa, percabangan dan pembentukan konidia jamur. Salah satu senyawa kimia yang terkandung pada $C$. alata adalah senyawa steroid. Subhisha dan Subra-moniam (2005), menambahkan bahwa senyawa steroid dapat berfungsi sebagai anti jamur karena sifat lipofilik yang dimiliki oleh steroid dapat menghambat perkecambah- an konidia dan perbanyakan miselia pada jamur.

Ekstrak sederhana daun tua tumbuhan $C$. alata memiliki persentase penekanan yang paling tinggi terhadap pertumbuhan koloni, luas koloni, jumlah konidia, berat basah dan berat kering koloni dan daya perkecambahan konidia jamur C. gloeosporioides. Diduga hal ini disebabkan karena senyawa anti jamur yang terkandung dalam ekstrak daun tua lebih tinggi dibandingkan dengan bagian lainnya. Penelitian Ehiowemwenguan et al. (2014) menyatakan bahwa ekstrak daun tua tumbuhan $C$. alata mengandung senyawa glikosida, flavonoid, minyak atsiri, alkaloid, saponin dan tanin. Senyawa glikosida adalah senyawa antijamur yang termasuk kedalam golongan glikosida antrakuinon yang biasanya terkandung pada daun yang berwarna hijau pekat (Anonim, 2010). Kardinan (1999) menambahkan bahwa senyawa kimia yang terdapat dalam minyak atsiri dapat menghambat perkecambahan spora dan pertumbuhan hifa. Menurut Lumbessy et al. (2013) kandungan total senyawa flavonoid pada C. alata adalah sebesar $26,86 \mathrm{mg} / \mathrm{ml}$.

Selain itu penelitian Faruq et al. (2010) menyatakan bahwa pada ekstrak daun tumbuhan $C$. alata terdapat kandungan senyawa steroid. Pada tumbuhan, senyawa steroid digunakan sebagai bentuk pertahanan diri dari serangan berbagai mikroba.

\section{KESIMPULAN}

Ekstrak sederhana bagian tumbuhan C. alata dapat menekan pertumbuhan jamur $C$. gloeosporioides penyebab penyakit antraknosa pada tanaman cabai. Ekstrak bagian tumbuhan $C$. alata yang memiliki persentase penekanan tertinggi adalah daun tua, dengan persentase penekanan luas koloni sebesar 64,30\%, jumlah konidia $82,41 \%$, berat basah dan 
berat kering masing-masingnya 37,77 dan $29,8 \%$ serta penekanan daya kecambah konidia $79,96 \%$.

\section{DAFTAR PUSTAKA}

Ali M, Y Venita dan B Rahman. 2009. Uji beberapa konsentrasi ekstrak daun Mimba (Azadirachta indica A. Juss) untuk pengendalian penyakit Antraknosa yang disebabkan oleh jamur Colletotrichum capsici pada buah cabai merah pasca-panen. Agricultural Science and Technology Journal 11(1): 2-5

Anonim. 2010. Kandungan senyawa metabolit sekunder ketepeng cina. http://www.kandungan senyawa ketepeng cina. [1 September 2014].

AVRDC. 2003. Evaluation of phenottype and moleculer criteria for the identification for Colletothricum spesies causing pepper Antrachnose in Taiwan. AVRDC Report. p. 58-59.

Aulifa DL, INP Aryantha dan Sukrasno. 2014. Aktivitas anti jamur ekstrak metanol dari tumbuhan rempahrempahan. Jurnal Ilmu hayati dan fisik 16(1):12-18.

Badan Pusat Statistik. 2014. Produktivitas Bawang Merah 2009-2012. http:// www.BPS.go.id [7 Maret 2015].

Dalimartha S. 2009. Atlas tumbuhan obat Indonesia. Pustaka bunda. Jakarta.

Doughari JH dan B Okafor. 2007. Antimicrobial activity of Senna alata Linn. East and Central African Journal of Pharmaceutical Sciences 10: 17-21.

Efri. 2010. Pengaruh ekstrak berbagai bagian tanaman Mengkudu (Morinda citrifolia) terhadap perkembangan penyakit Antraknosa pada tanaman cabe (Capsicum annum L.). Jurnal HPT Tropika 1(10): 52-58.

Ehiowemwenguan G, JE Inetianbor dan JM Yakubu. 2014. Antimicrobial

qualities of Senna Alata.
Department of Microbiology
University of Benin. 9 (2):47-52.

Faruq ZU, UA Rahman, $M$ Bello $M, O$ Obianke dan FA Atiku. 2010. Antibacterial activity of the active component of Cassia Alata. Nigerian Journal of Basic and Applied Science. 18:97-100.

Gautam AK. 2014. Colletotrichum gloeosporioides: Biology, pathogene-city, and management in India. Journal of Plant Physiology and Phatology 2(2): 2-11.

Gusti A. 2003. Uji konsentrasi air perasan daun cengkeh (Syzgium aromaticum L) terhadap pertumbuhan jamur Altenaria porrii (Ell.) Cif. penyebab penyakit bercak ungu pada bawang merah secara In Vitro. [Skripsi]. Fakultas Pertanian. Universitas Andalas. Padang.

Hariati N. 2007. Analisis keanekaragaman 23 genotipe cabai (Capsicum sp.) berdasarkan penampakan fenotipik serta ketahanannya terhadap penyakit Antraknosa (Colletothricum sp). [Skripsi]. Departemen Agronomi dan Hortikultura Fakultas Pertanian. IPB. Bogor.

Kardinan A. 2011. Penggunaan pestisida nabati sebagai kearifan lokal dalam pengendalian hama tanaman menuju sistem pertanian organik. Jurnal Pengembangan Inovasi Pertanian. 4(4) : 262-278.

Khairul U. 1991. Uji efektivitas beberapa fungisida dalam pengendalian jamur Phytium debaryanum Hess penyebab penyakit rebah kecambah pada persemaian tomat. [Skripsi]. Fakultas Pertanian Universitas Andalas. Padang.

Lumbessy M, J Abidjulu dan JJE Paendong. 2013. Uji total flavonoid pada beberapa tanaman obat tradisional di Desa Waitina kecamatan 
Mangowali Timur Kabupaten Kepulauan Sula Provinsi Maluku Utara. Jurnal MIPA Universitas Sam Ratulangi Online. 2(1): 50-55.

Lutfiyanti R, WR Ma'ruf dan EN Dewi. 2012. Aktivitas anti-jamur senyawa bioekstrak Gelidium latifolium terhadap Candida albicans. Jurnal Pengolahan dan Teknologi Hasil Perikanan 1(1): 1-8.

Natta L, Orapin, Krittika dan Pantip. 2008. Essensial oil from Zingiberaceae for anti food-borne bacteria. International Food Research Journal15(3): 337-346.

Nwachukwu OE dan JO Osuji. 2008. Evaluation of plant extracts for antifungal activity against Sclerotium rolfsii causing cocoyam cormel rot in storage. Research Journal of Agriculture and Biological Sciences 4(6): 784-787.

Owoyale JA, GA Olatunji dan SO Oguntoye. 2005. Antifungal and Antibacterial activities of an alcoholic extract of Senna alata leaves. Journal Applied Science Environment Management 9 (3) : 105-107.

Park. 2005. Differential interaction between pepper genotypes and Colletothricum isolates causing Anthracnose. Thesis. Seoul North University. Korea.

Ratulangi MM, DT Sembel, CS Rante, MF Dien, ERM Meray, M Hammig, M Shepard M, G Camer dan G Benson. 2012. Diagnosis dan insiden penyakit pada beberapa varietas tanaman cabe di Kota Bitung dan Kabupaten Minahasa. Jurnal Eugenia 18(20): 81-88.
Subhisha S dan A Subramoniam. 2005. Antifungal activities of a steroid from Pallavicinia lyellii, a Liverwort. Tropical Botanic Garden and Research Institute. India.

Suleiman MN, SA Emua dan A Taiga. 2008. Effect of aqueous leaf extraction a spot fungus (Fusarium Sp) isolated from Compea. American-Eurasian Journal of Sustainable Agriculture 2(3):261-263.

Syukur M, R Yunianti, Rustam dan Widodo. 2013. Pemanfaatan sumber daya genetik dalam perakitan varietas unggul cabai (Capsicum annum) tahan terhadap penyakit Antraknosa yang disebabkan oleh Colletothricum sp. Jurnal Ilmu pertanian indonesia 18 (2) : 67-72.

Wati DK, Yuliarni dan LS Budipramana. 2012. Pengaruh pemberian filtrat alang-alang (Imperata cylindrica L.) terhadap pertumbuhan miselium jamur Trichoderma sp. yang hidup pada media tanam jamur tiram putih (Pleurotus streatus). Lentera Bio 1(2): 93-98.

Widodo. 2007. Status of chili Anthracnose in Indonesia. In first International symposium and chili Anthracnose. National Horticultural Research Institute, Rural Development of administration. Korea.

Wongkaew P dan W Sinsiri. 2014. Effectiveness of ringworm Cassia and turmeric plant extracts on growth inhibition against some important plant pathogenic fungi. American Journal of Plant Sciences 5: 615-626. 